\title{
Gandhi, Marx and the Warrior Tradition
}

Towards Androgynous Liberation

ALI A. MAZRUI

The University of Michigan, Ann Arbor, U.S.A.

\section{I}

N THE STRUGGLE for equality and liberation in this century three forms of resistance have been particularly important in Eastern and Southern Africa. One form is rooted in indigenous culture and has sought comfort in African symbols and drawn inspiration from African heroes. This is the form of resistance associated with the warrior tradition.

The second form of struggle has been partly inspired by the whole tradition of passive resistance as dramatized by the techniques used by Mohandas Gandhi against white racism in South Africa and British imperialism in India.

The third form of struggle has been inspired by the Marxist revolutionary tradition and has so far found its most successful fulfilment in the former Portuguese colonies of Mozambique, Guinea-Bissau and Angola.

The warrior tradition was at play in some of the very earliest instances of resistance against the penetration of the white man in Southern Africa. These early struggles are now sometimes referred to in the literature as cases of "Primary resistance".

Partly as a result of stimulation provided by the Dar es Salaam School of African History, increased attention has recently been paid to this phase of "primary resistance" when Africa first had to confront western intrusion. The argument of scholars like Terrence Ranger for Eastern Africa and Michael Crowder for Western Africa identifies those early armed challenges by Africans against colonial rule as the very origins of modern nationalism in the continent. ${ }^{1}$ By this argument Tanzania's ruling party and its function as a liberating force has for its ancestry both the Maji Maji and the pre-Maji rebellions against German rule from the 1880's onwards. African struggles against colonial rule did not begin with modern political parties and western trained intellectuals, but originated in those early "primary resisters" with their spears poised against western military technology.

1 Consult especially T. O. Ranger, "Connexions between 'Primary Resistance' Movements and Modern Mass Nationalism in East and Central Africa," Parts I and II, Journal of African History, Vol. IX, Nos. 3 \& 4, 1968, pp. 437-453; and pp. 631-641. 
This author is basically in sympathy with the Dar es Salaam School of African historiography, but with one important difference. While the Dar es Salaam historiography regards the Nkrumahs and Nyereres of modern Africa as the true heirs of those primary resisters, we believe that it is much more the liberation fighters in southern Africa that have really carried the mantle of the original primary resisters.

But it is more the fighters in the field rather than the westernised leaders who have shown affinity with Africa's ancestral combat culture. The rural recruits into liberation movements have often been steeped in traditional norms and perspectives. Their concepts of valour and honour, their conceptions of solidarity and loyality, have all been partly conditioned by important aspects of African culture. That is one major reason why "tribalism" or ethnicity has been so resistent among liberation fighters in Southern Africa, especially in Angola and Zimbabwe (Rhodesia).

Historians have used the term "primary resistance" chronologically, applying it to the earliest times of confrontation between the indigenous fighter and the foreign intruder.

But it is at least as defensible to use the term "primary resistance" in a cultural rather than a chronological sense. In this cultural meaning primary resistance could be taking place today - provided it is a form of resistance which draws its "primary inspiration" from indigenous symbols and values. The Mau Mau insurrection was therefore in part a case of primary resistance in this cultural sense although chronologically it took place almost on the eve of Kenya's independence. Similarly UNITA (The National Union for the Total Independence of Angola) was nearer to being an instance of primary resistance in its use of indigenous values and symbols than was MPLA (the Popular Movement for the Liberation of Angola). This was partly because UNITA was much more of a rural movement than MPLA.

If we accept this cultural sense of "primary" we may then relate the warrior tradition to primary resistance, the Gandhian tradition to passive resistance and the Marxist tradition to revolutionary resistance.

In earlier chapters we examined linkages between military and sexual symbols. Virility and valour were often intertwined in cultural terms.

In this chapter we have to note that primary resistance is connected with masculinity, passive resistance with feminine techniques and revolutionary resistance with both. The warrior tradition once again asserts its manliness, Mahatma Gandhi displays feminine virtues and Karl Marx becomes a prophet of androgyny or sexual parity.

Let us examine these three dimensions as we relate them to the African struggle for social justice in its wider implications.

\section{Masculine Warriorhood and Primary Resistance}

The Mau Mau movement, in rebellion against British rule and white settler occupation of African land in Kenya, constituted the first major resurrection of 
the warrior tradition in recent East African history. The Kikuyu mobilized themselves into armed rebellion against European settlerdom. The Kikuyu fighters in the forests and the hills of the Aberdares became for a while true heirs of that heritage of primary resistance. The Kikuyu went back to reactivate primeval symbolism, and resurrect important elements of traditional Kikuyu virtues as a basis for establishing a military solidarity against the colonial presence in Kenya.

The connection between martial symbolism and sexual symbolism remains a major aspect of the oath of allegiance demanded from the Mau Mau warriors. We have details of the Batuni oath. The new warrior initiate was first stripped naked, and seated facing the oath administrator. Then a long strip of goat's meat was placed around the neck of the new initiate. One end lay across the chest of the naked man and the other dropped down his back around his waist several times, and then between his legs. The new initiate was ordered to hold this end of the goat's meat up against his penis. On the floor were the two eyes of an uncastrated he-goat, called a "Kihei". The word itself meant "uncircumcised youth", but paradoxically it was used during the Mau Mau insurrection to refer to a man who had taken the Batuni oath.

The oath itself did not demand total sexual abstinence, but forbade the use of prostitutes and the seduction of "other men's women". These particular prohibitions were to discourage the danger of betrayal by temporary sexual companions, such as prostitutes. They were also designed to discourage the warriors from fighting with each other over women. But once the Mau Mau fighters were in the forests, total sexual abstinence was demanded among some groups. And in some of the detention camps, where the possibility of having intercourse with women detainees was possible, special codes were self-imposed by the detainees against sexual relations while they were all behind bars. ${ }^{2}$

The Mau Mau did use aspects of that old discipline which Shaka had demanded of his own warriors but the movement did not push the particular discipline to total extremes.

There were other instances in the Mau Mau movement linking sexual with martial symbolism including the use of menstrual blood for certain oath-taking ceremonies in at least some sections of the movement. What was happening was an attempt to provide a sense of sacred awe to counterbalance belief in the invincibility of the white man which the colonial experience had so far consolidated. Let us remind ourselves that the warrior tradition earlier in the century had been badly damaged by two terrors which had come with the white man - the terror of gunfire and the terror of hellfire. The terror of gunfire was what the new military technology of the white man was all about. Those early primary resisters against the European intrusion discovered before long

2 Consult Karigo Munch, The Hard Core (Richmond, B.C., Canada: LSM Information Center, 1973), pp. 19, 22, 43; Don Barnett and Karari Njama, Mau Mau from Within (New York and London: Monthly Review Press, 1966), and J. M. Kariuki, 'Mau Mau' Detainee (London: Oxiord University Press, 1963). 
the overwhelming superiority of the cannon as against the spear, the gun as against the bow and arrow. In the words of the English writer, Hillaire Belloc:

"Whatever happens we have got

The Maxim gun, and they have not."3

European technology soon overrode and demoralized the resisters. The new terror of gunfire initiated the decline in the warrior tradition.

The decline was reinforced by the terror of hellfire which came with Christianity. Death for millions of Africans was now given a new meaning. African ancestors were cut down to size, denounced as insignificant by the missionaries of the new religious order. A new god was proclaimed, and a new fear of damnation was propounded. Some African Christians, like many other Christians before them, accepted the concept of hellfire at its face value; others equated it simply with the threat of damnation after death. Whatever interpretation, literal or symbolic, the new religion had come with a new system of punishment and rewards. The power of all indigenous beliefs began to decline; the authority of the village medicine man was struggling against the challenges of local missionary schools. The old order was partially disintegrating - and with it, the warrior tradition.

Movements like that of Mau Mau had to invent new forms of ritualized damnation in order to outweigh the combined demasculating effect of the fear of the white man's gunfire and the Christian priest's hellfire.

Christianity had in addition damaged the warrior tradition in Africa by proclaiming the ethic of "turning the other cheek". Meekness was regarded as a virtue even for otherwise virile and valiant men. A version of Christianity which had hardly even been truly implemented in Europe, and which had in part become anachronistic on its home ground, was now bequeathed to African school-children and peasants. The god of love was mobilized behind the task of "imperial pacification." The message of Christianity discouraged Africans not only from fighting each other but also from resisting the colonial presence.

Again, a movement like Mau Mau had to help Kikuyu Christians transcend the conditioning of "turning the other cheek," as well as overcome the terror of external Christian damnation. Those oaths of Mau Mau combining sexual symbolism with militant commitment were part of the process of countering the demasculating consequences of the colonial experience.

The Mau Mau movement was militarily defeated by the British. But it was clearly a victory of the vanquished. The political triumph went to the African people, even if the military successes were retained by the colonial people. The stranglehold of the white settlers on Kenya was at last broken and before long Kenya was preparing for independence.

The Mau Mau movement was also the first great African liberation move-

3 Stavrianos links Belloc's cynical observation and the literature of self-righteous power to Social Darwinism as an ideological movement. See L. S. Stavrianos, Man's Past and Present: A Global History (Englewood Cliffs, N.J.: Prentice Hall, 1971), pp. 270-273. 
ment of the modern period. All the efforts which are now being made in Southern Africa to consolidate resistance, organize sabotage, and seek to dispel white power and privilege, have for their heroic ancestry that band of fighters in the Aberdare forest of Kenya. The warrior tradition was at least temporarily revived at a critical moment in Kenya's history.

The revival of primordial symbolism - which was so striking in the history of Mau Mau - has also been discerned in more subtle forms in the struggle for the liberation of Rhodesia since Ian Smith unilaterally declared its "independence" in 1965. As in the case of Mau Mau, a return to cultural ancestry has included in Zimbabwe a return to aspects of indigenous religion as well. Hostility to Christianity has also reared its head among the liberation fighters. In the rural areas the internecine fighting among the rival nationalist parties has included the burning of churches. And many a young man has re-established contact with the experience of spirit possession. ${ }^{4}$

Basil Davidson has also drawn our attention to the fact that an oath taken by guerrillas in the names of the great spirits of Chaminuka and Nehanda forms part of a "truly impressive" continuity. ${ }^{5}$

The Zimbabwe nationalist, Nathan Shamuyarira, has also observed the effort often made to give meaning to the Zimbabwe struggle through the utilization of the African heritage itself.

\footnotetext{
"In rural areas meetings become political gatherings and more..., the past heritage was revived through prayers and traditional singing, ancestral spirits were evoked to guide and lead the new nation. Christianity and civilization took a back seat and new forms of worship and new attitudes were thrust forward dramatically..., the spirit pervading the meetings was African and the desire was to put the twentieth century in the African context." 6
}

A grandson of a rebel leader killed in 1897 invoked the memory of Chaminuka, the great prophet who provided the focus of Shona solidarity in the nineteenth century.

Joshua Nkomo, the Zimbabwe leader, on arrival back home from abroad in 1962, was met at the airport by a survivor of the 1896-9 rebellion. He presented a spirit axe to symbolize the martial succession and the transmission of the warrior torch. ${ }^{7}$

In their campaign in northern parts of Rhodesia more recently the liberation fighters have reportedly shown respect for traditional beliefs and customs, and this has helped the movement to build a more effective infrastructure of

4 Reverend S. Madziyere "Heathen Practices in the Urban and Rural Parts of Marandellaz Area," Themes in the Christian History of Central Africa, eds. T. O. Ranger and John Weller (London, 1975), pp. 76-82. I am greatly indebted to Professor Ranger for stimulation and for bibliographical guidance.

5 Basil Davidson, The Africans: An Entry to Cultural History (London, 1969), p. 255.

6 N. S. Shamuyarira, Crisis in Rhodesia (London, 1965) pp. 68-9.

7 Shamuyarira, ibid. See also Ranger, Connections between 'Primary Resistance Movements and Modern Mass Nationalism in East and Central Africa," Part II, op. cit. pp. 635-6. 
popular support. Some of the campaign zones have at times been named after senior spirit mediums. Indeed, some of those mediums have been known to operate from guerilla camps. The link between the warrior and the prophet has often been permitted to persist in these movements. Manliness, valour and some degree of ancestral devoutness have gone alongside the spirit of modern liberation.

\section{Feminized Warriorhood and Passive Resistance}

Almost inevitably the strong connection between masculinity and warfare has resulted in a similar connection between kindliness and femininity. The example of Gandhi we mentioned earlier is certainly a case in point. The great prophet of nonviolence found himself torn between serving as a father figure and acting as a mother symbol. At a more personal level Gandhi had played this second role for a young orphan girl named Manu. The girl had previously been adopted by Gandhi's wife Kasturba. Kasturba on her death bed had asked her husband to take her place as a mother to Manu. Gandhi took this role so seriously that he assumed the task of teaching the girl about womanhood, and watching her physical development, and later actually sharing a bed with her as if Gandhi was another woman. The young woman's memoirs captured this strong maternalism in Gandhi's relationship with her when she entitled her book, Bapu, My Mother. ${ }^{8}$

Erikson points to a "persistent importance in Gandhi's life of the theme of motherhood, both in the sense of a need to be a perfect and pure mother, and in the sense of a much less acknowledged need to be held and reassured, especially at the time of his infinite loneliness." But to the extent that the loneliness might have been aggravated by a long period of sexual renunciation, we have in the story of Gandhi an illustration of the tense relationship between celibacy and masculinity, nonviolence and manliness.

The same problem arises with regard to Christianity. Is Christianity, in the ultimate analysis, a feminine religion? Does the centrality of forgiveness make the Christian God less manly than the Jewish Jehovah? Is the transition from the Old Testament to the New Testament a process of the demasculation of God? Does the centrality of love as a divine attribute make the Christian God less manly than Islam's Allah? Before he was assassinated and became a black martyr, Martin Luther King was sometimes denounced by some of his more militant black critics as "Martin Luther Queen." 9

What we have in these questions is the prior question of whether certain symbols are counter-phallic. Are there aspects of Christian imagery which go almost purposefully against phallic symbols without being sexually neutral?

8 Manubehn Gandhi, Bapu, My Mother (Ahmedabad: Navajivan, 1949). Erikson, Gandhi's Truth, op. cit., pp. 403-4.

9 For Gandhi's influence on King consult for example, Martin Luther King, Stride Toward Freedom (New York: Ballantine Books, 1958). pp. 76-77. 
It may have started with the whole concept of a virgin birth. Intercourse was not necessary to produce Mary's baby boy. And yet the very insistence that the conception of the baby was "immaculate," the very consciousness of virginity as the basis of this supreme miracle, is indeed counter-phallic. God did not really have to send His son as His own price for forgiving the human race. And even if $\mathrm{He}$ did send His son, the son did not have to be born at all. And if $\mathrm{He}$ had to be born and have a human mother, why not also a human father? The two natures of Jesus Christ on earth could still have been maintained without the notion of a virgin birth. But the basic counter-phallicism of Christian mythology starts precisely with the virgin birth.

Later on the emphasis on celibacy for the priests of the church prior to the reformation was a continuation of the counter-phallic tradition.

The coming of the Christian religion in Africa has included these counterphallic themes. To a certain extent Christianity has softened African masculinity. Some might even argue that it initiated a process of demasculation. The movement of "pacification" which imperialist powers helped to initiate reduced tribal confrontations. The idea of "loving thy neighbour", though still painfully unfulfilled in Africa, denuded warfare of some of its previous mystique.

"Turn the other cheek!" - This was the most feminine imperative of them all. Only a woman turned the other cheek upon being punished by her man. And even a woman attempted at times to shield herself with her arms. But the principle of turning the other cheek was part of the feminine baggage that came with Christianity.

Then there was celibacy for those who entered holy orders, and monogamy for everybody else. Sexual richness which had been so much a part of Africa before the onslaught of neo-Victorian prudery was now to be drastically circumscribed. The missionary schools were the great champions of a new prudish civilization. Suitably "modest" uniforms were devized for girl students; suitably "smart" uniforms came into being for the boy. The boys and girls were usually in quite separate schools. Visits across the sexual divide were either strictly discouraged or rigidly controlled. Most African forms of dances were abolished altogether, for the movements were interpreted as "sinful". Phallic dances retreated before the accusing finger of the new self-righteous creed.

Behind it all was the virgin birth of the son of God, when the male was dispensable. Behind it all was also the celibate life of Jesus, when female sexual companionship was dispensable. The counter-phallic stream of Christianity had begun to erode the banks of Africa's masculinity.

And yet Gandhism was clearly not an exercise of "turning the other cheek." It was not even a case of nonviolence broadly defined. Gandhism was a philosophy of nonviolent resistance. The idea was not to accept injustice meekly, but to fight it nonviolently.

It was between 1906 and 1908 that a civil disobedience campaign was launched in South Africa under the leadership of Gandhi, directed against laws in the Transvaal which required Indians to carry registration certificates. The movement did have an impact on African opinion in South Africa. Leo 
Kuper has reminded us of a series of Gandhian protest experiments in South Africa in those early years. African women in Bloemfontein used the technique of civil disobedience in 1913 in their protests against the extension of pass laws to them by municipalities in the Orange Free State. The women's movement spread to other towns, and continued for a few years. In 1919 the African National Congress started experimenting with these techniques in Johannesburg. The Communist Party in Durban in 1930 also went "Gandhian". The Indians in South Africa resisted in 1946 in a similar way in protest against the Asiatic Land Tenure and Indian Representative Act. Meanwhile the struggle in India itself was helping to give Gandhian tactics global visibility and capturing the imagination of politically conscious Blacks in South Africa, as well as elsewhere. Then came the South African campaign for the Defiance of Unjust Laws of 1952, again using Gandhian techniques of civil disobedience. But in the very wake of such tactics, the system in South Africa was closing up and getting more intolerant.

The Gandhian resistance in South Africa in the early 1950's was an alliance between Blacks and Indians in the Union. It was in July 1951 that the African and Indian Congresses and the Franchise Action Council of the Coloureds appointed a Joint Planning Council. The aim was to coordinate the efforts of Africans, Indians, and coloured peoples in a mass campaign for the repeal of the pass laws, the Group Areas Act on racial segregation the Separate Representation of Voters Act which was moving in the direction of further curtailment of the political rights of Coloureds, and the Bantu Authorities Act seeking to ensure a re-tribalization of Africans. The campaign was successful in terms of the degree of involvement of the three groups, but a failure in terms of its aims. The failure was even more significant as an indicator of the limits of Gandhism, and the implications of this for pacific socialization in Africa at large.

Meanwhile strategies of resistance to racial domination in South Africa were regionalist rather than purely national. In September 1958 there had come into being further north a movement called the Pan African Freedom Movement of East and Central Africa (PAFMECA). The aim of the organization was to coordinate nationalistic movements mainly in British West and Central Africa and ensure periodic consultations on strategy and methods of agitation for self-government. At that time nationalism in British Africa was still significantly under the influence of Gandhism.

Yet today, Southern Africa especially presents a mixture of domestic and international violence related to the wider international environment.

Violence in Southern Africa has been both inter-racial (white against black) and intra-racial (black against black). Angola, especially since April 1974, has been a particularly acute case of black intra-racial violence. The Angolan tragedy illustrates the fragility of any sense of nationhood in the country; indeed, it illustrates how easily violence against colonialism could then lead on to an acute primary struggle for power among black nationalists themselves.

Rhodesia (Zimbabwe) has encompassed both inter-racial violence (black against white) and periodic eruptions of internecine black violence. 
The contemporary political morality in Black Africa is supportive of anticolonial violence and, to a large extent, of violence directed against domestic white minority rule. But this supportive African attitude towards inter-racial violence in the name of national liberation is a relatively recent development. The earlier phases of African nationalism showed a strong African distrust of violence as a strategy of liberation.

In this regard the ideological history of President Kenneth Kaunda of Zambia is particularly telling. Fergus Macpherson, Kaunda's biographer, reminds us that Kaunda's early nationalistic ideas were greatly influenced by Mohandas Gandhi. Kaunda saw that violence was indeed a tempting strategy for those who were denied alternative means of correcting injustices. But Kaunda insisted on the need for passive resistance (Satyagraha):

"I could not lend myself to take part in any (violent) campaigns. I reject absolutely violence in any of its forms as a solution to our problem." 10

Although Kaunda was not basically a philosopher he did place his attachment to nonviolence in the context of a broader philosophical view of the world. Curiously enough Kaunda seemed to believe that there was something unnatural in being nonviolent. He did not share the romanticism which saw man as being essentially peaceful. On the contrary, Kaunda felt that "Man, just like any other animal, is violent." 11

Like the late Martin Luther King of the United States, Kaunda virtually saw Gandhi as playing Lenin to Jesus's Marx. Just as Lenin had operationalized the teachings of Marx in a concrete political situation, so had Gandhi operationalized the teachings of Jesus and converted them into a political strategy. The theme of Gandhism as a politicisation of the love-ethic of Jesus recurs in Kaunda's intellectual growth. This is related to the conversion of Kenneth Kaunda - "Gandhi and Jesus had a special magnetism for the twenty-four year old Kaunda. He saw them as realists with a vision and rejected the popular notion that this was contradiction in terms." 12

Alice Lenshina's Lumpa Church posed the most serious domestic challenge to Kaunda's "nonviolence" soon after the attainment of self-government; while liberation movements in "Portuguese Africa" and the implication of Ian Smith's U.D.I. later posed external challenges to Kaunda's legacy of Gandhism. Alice was one woman who served as prophetess to new religious warriors in Zambia. ${ }^{13}$

Macpherson discusses the struggle against the Lumpa Church, Kaunda's

10 Kenneth Kaunda and Colin Morris, Black Government (Lusaka: United Society for Christian Literature, 1960). The emphasis is original.

11 See the journal, New Africa, Vol. 5, No. 1, January 1963, p. 4.

12 Fergus Macpherson, Kenneth Kaunda of Zambia: The Times and the Man (Lusaka and London: Oxford University Press, 1974), p. 105.

13 Consult Andrew D. Roberts, "The Lumpa Church of Alice Lenshina," in Robert I. Rotberg and Ali A. Mazrui (eds.), Protest and Power in Black Africa (New York: Oxford University Press, 1970), pp. 513-570. 
initial demand for Alice Lenshina "dead or alive", and his more conciliatory attitude later on. But Kaunda's biographer does not fully understand this Lenshina shock to Kaunda's universe of values. He does not even directly relate it to Kaunda's concept of the state, which is part Weberian, part Marxist, part Christian and part Gandhian. In Kaunda's words as cited by Macpherson:

\footnotetext{
"Gandhi tried to organise things in such a way that the state must eventually wither away-for the whole state machinery has in it the seeds of violence-when man would do to others what he would like them to do to him."14
}

In this short quotation from Kaunda we have the Marxist concept of the state as an instrument of class oppression; we have Weber's idea that the state exercises a monopoly of the legitimate use of physical force; we have Gandhi's distrust of the state in favour of village industry and general decentralization; we have the marxist idea of the withering away of the state and its replacement with a classless society; and we have Jesus's Golden Rule as something which can only be adequately realized when Marx's dream of a classless society is finally brought to fruition.

As head of state, Kaunda was inevitably in charge of something which had the seeds of violence. Alice Lenshina shocked Kaunda into experiencing what state-management was all about.

By 1975, Kenneth Kaunda seemed to be in a diplomatic alliance with Prime Minister Vorster of South Africa in pursuit of a constitutional settlement in Rhodesia. The President of Zambia was even prepared to meet and have discussions with the prime minister of the most racist regime in Africa's history. The word détente had entered the political vocabulary of Southern Africa, affirming the need for white and black to live together in relative peace. Prime Minister Vorster was the chief architect of the principle of détente, and Kenneth Kaunda was perhaps his most sensational convert.

Was Kaunda returning to Gandhism? Had he rediscovered Satyagraha, or "Soul Force", which Mohandas Gandhi had espoused as an alternative to violent resistance?

If Kaunda had rediscovered Mahatma Gandhi through John Vorster, history had once again indulged its own mischievous sense of humour. It was after all in South Africa, as we have noted, that Gandhi had first experimented with Satvagraha much earlier this century. We know that within South Africa the Gandian experiment failed. Kenneth Kaunda later became one of the Mahatma's most enthusiastic black converts. Kaunda retreated from Satyagraha partly in the face of domestic violence in Zambia after independence, and partly in response to hardening attitudes in Southern Africa as a whole. The question which has arisen in the 1970's is whether a new Gandhian mood is in the air in the region - a readiness to try alternative pressures on the remaining racist regimes in Southern Africa, and let "Soul Force" destroy apartheid in the fullness of time.

14 See Macpherson, ibid. pp. 105-6. 
In reality, the chances of a peaceful transition to social justice in South Africa and Rhodesia without additional violence are remote. The region is likely to need Gandhians, Warriors and Radical Guerillas before racial equity finally prevails.

But of even longer-term consequence than inter-racial violence will be the cleavages of black against black. These are likely to be the most obstinate. They are also likely to tax the ingenuity of Africa to find both preventive and curative measures. Violence as a form of political pathology will need more than traditional witchdoctors or modern psychiatrists. It will need a long but vital process of creating self-discipline and establishing self-policing techniques to govern Africa's relations with itself.

In this quest for new approaches to problems of violence, Kenneth Kaunda's name looms large. More a strategist than a theoretician, more a statesman than a philosopher, Kenneth Kaunda gropes for answers about some of the most basic questions of man's relations with man. Kaunda is a nationalist who is ready to give the oppressor the benefit of the doubt; he is a humanist capable of supporting armed and violent insurrection; he is a world figure who is capable of being concerned about a village; he is a political warrior who is capable of bursting into tears.

Yet in those very tears we are back to feminine symbolism in culture. The convert to Gandhism has retained the supremely feminine prerogative of unabashed capitulation to tears on relatively casual emotional stimulus. The sublimated maternalism of Gandhi has found its African counterpart in Kenneth Kaunda.

\section{Androgynous Warriorhood and Revolutionary Resistance}

It is with the intrusion of modern revolutionary ideas in Southern Africa that androgynous warriorhood became at last a serious aspiration for some of the liberation movements. We define androgynous warriorhood as a principle which seeks to end masculine monopoly of the skills of war. Historically, before total European control was established, Angola had indeed known strong women with warrior skills, from a warrior queen to peasant fighters. But on balance the principle of masculine monopoly of the war-machine was the order of the day in Angola as elsewhere.

Perhaps more fascinating was the Dahomean experience with women fighters, especially in the nineteenth century. It started earlier when the Kings of Dahomey had at times conscripted some of their wives as armed palace guards, especially in times of emergency. In the nineteenth century the practice became institutionalized. After a dynastic coup in 1818 the royal pretender, King Gezo, selected from among non-Dahomean captive girls a corps of fighters to defend him in case of further trouble. These women had certain privileges as both his soldiers and his wives, and their loyalty to the king was on the whole strengthened by their vested interest in his survival.

King Gezo died in 1858. In the years which followed recruitment into the 
Amazons' Corps was no longer restricted to captive girls, but was extended to Dahomean women, some of whom came from high ranking families.

Another significant change took place. The Amazons in time became not merely the monarch's civil guard but important units in the Dahomean army. From about 1840 onwards they started getting involved in foreign wars, and soon earned a reputation as particularly ferocious and often cruel fighters.

Psychological explanations of their ferocity have included the sexual frustrations which emanated from their being all the wives of a single man - the king.

"These female soldiers had all the privileges of important royal wives; they lived in the royal palaces, they had their food prepared for them; anyone who met them on the roads had to make way for them. They had also to obey the regulations which governed the lives of the King's wives. The most onerous of these was that, although they could only enjoy the favours of thcir royal spouse infrequently, they were forbidden any relations with other men. Any deviation from this rule was punishable by death. No doubt this enforced state of chastity goes a good deal towards explaining their ferocity."15

In the course of much of the rest of the nineteenth century the "standing army" of Dahomey had regular male and female units. At its peak the size of the army in an emergency rose up to twelve thousand warriors, nearly half of whom were women.

The Amazons of Dahomey were destroyed as a fighting force by the French colonizers in 1892. The male units of the Dahomean army were almost equally decimated. One of the most dramatic experiments in androgynous warriorhood anywhere in the world came abruptly to an end.

And yet the Dahomean experiment was not an ideal instance of androgynous warriorhood. In the first place the fighting units of men and women were kept separate. But even more fundamental was that the primacy of the male in the political system as a whole was not in question. The Amazons were after all the king's wives. And while the monarch could have more than four thousand wives at a time, a wife could enjoy the favours of another man only on pain of death.

Androgyny as a negation of sexism cannot therefore be credited to the Dahomean experiment. As an ideological ideal androgyny is a child of both western liberalism and western socialism. Afterall, both John Stuart Mill and Karl Marx championed the liberation of women in the nineteenth century.

In much of colonial Africa it was western liberalism which began to influence events in the direction of greater equality for women. Girls were encouraged to go to school, polygamy was sometimes taxed by the colonial master, and female circumcision where it was practised fell under the shadow of Christian and imperial disapproval. There is little doubt that in much of Africa important new areas of feminist freedom were opened up by the imperial order itself.

15 David Ross, "Dahomey" in West African Resistance: The Military Response to Colonial Occupation, edited by Michael Crowder (London: Hutchinson and Co., 1971), p. 149. 
Yet warriorhood even under western liberalism continued to remain a preserve for the male. Could this military monopoly by men be reconciled with a genuine liberation of women?

It is among the leftist regimes of Africa - especially those in former Portuguese colonies - that the principle of androgynous warriorhood is beginning to be seriously entertained. FRELIMO in Mozambique had begun to use women in the struggle against the Portuguese by the late 1960's. The radical nationalist thrust in Guinea-Bissau under the Cabrals had initiated similar experimentation. MPLA in Angola as an initially urban movement began to tap sophisticated urbanized female talent in ways which were less dramatic than but still comparable to those which had once been used by the National Liberation Front (FLN) in Algeria in their war against the French. In the vivid words of Franz Fanon, who shared the experience of fighting for Algerian resistance:

"Three metres ahead of you the police challenge a veiled woman who does not look particulary suspect. From the anguished expression of the unit leader you have guessed that she is carrying a bomb, or a sack of grenades, bound to her body by a whole system of strings and straps. For the hands must be free, exhibited bare, humbly and abjectly presented to the soldiers so that they will look no further."16

But with the conversion of the veil into a military camouflage the enemy gradually became extra alert.

"In the streets one witnessed what became a commonplace spectacle of Algerian women glued to the wall, over whose bodies the famous magnetic detectors, the 'frying pans' would be passed. Every veiled woman, every Algerian woman became suspect. There was no discrimination. This was the period during which men, women, children, the whole Algerian people, experienced at one and the same time their national vocation and the recasting of the new Algerian society." 1 ?

Fanon may have been exaggerating, but he certainly captured the androgynizing tendency of revolutionary resistance. Women gradually become radicalized. And if the revolutionary resistance lasts long enough, the androgyny may become a conscious morality and not merely a side-effect of sustained struggle.

Yet the patron saints of modern socialist revolutions, Marx and Engels, drastically underestimated the relevance of military factors for the status of women in society. The two thinkers were such consistent economic determinists that they saw relations between men and women in primarily economic terms.

They argued that it was because men controlled the means of production that the women had become servants and serfs. In the words of Engels:

"Today, in the great majority of classes, the man has to be the earner, the breadwinner of the family, at least among the propertied classes, and this gives him a dominating

16 Franz Fanon, Studies in a Dying Colonialism, translated from the French by Haakon Chevalier (New York: Monthly Review Press, 1965), pp. 61-62.

17 Ibid. 
position which requires no special privileges. In the family, he is the bourgeois; the wife represents the proletariat." 18

Engels assumed too readily that where women were effective economic producers, they attained high status. He thought "savages" and "barbarians" with economically active women respected their women more than western men respected western women:

"That woman was the slave of man from the commencement of society is one of the most
absurd notions that have come down to us from the period of Enlightenment of the
eighteenth century. Woman occupied not only a free but also a highly respected position
among all savages and all barbarians of the lower and middle stages and partly even of the
upper stage... People whose women have to work much harder than we would consider
proper often have far more real respect for women than our Europeans have for theirs.
The social status of the lady of civilization, surrounded by sham homage and estranged from
real work, is socially infinitely lower than that of the hard-working woman of barba-
rism...."19

What Engels did not seem to realise is that it is possible for women to work hard and be economically productive - and still enjoy low status in society. Kikuyu women work much harder than western women. They are economically more productive in relation to their society than western women are in relation to their own. But it is far from self-evident that Kikuyu women enjoy higher social status than do their western counterparts.

Engels did see the coming of the patriarchal family as a major disaster for women. But how did men manage to control the means of production in the first place? Did they not first have to control the means of destruction - the instruments of violence? Was it not masculine superiority in the skills of physical coercion which tilted the balance in the first place?

In the essay on "Armed Kinsmen and the Origins of the State" we have argued more fully that it was military factors rather than economic ones which initially gave men control over the political system. Primacy in the means of destruction rather than ownership of the means of production is the ultimate factor in the origins of sexism. This may not be neatly compatible with economic determinism but it explains a wider range of societies. The economic role of women varies enormously in different societies, while the military role of women is rather constant. Low status for women is almost universal; so is their limited military involvement. The subjection of women correlates much more neatly with the degree of their demilitarization than with the degree of their involvement in economic production.

Twentieth century Marxists are perhaps a little more sensitized to the importance of controlling the means of destruction than Marx and Engels seem to have been, inspite of the Paris Commune of 1871 .

18 Frederick Engels, "The Origin of the Family, Private Property and the State," (1884), Karl Marx and Frederick Engels Selected Works (New York: International Publishers, 1972), p. 510.

19 Ibid., pp. 489-490. 
In the course of World War I Lenin hoped that if the fighting in Europe continued long enough the bourgeois regimes might start enlisting women. Such enlistment could help to bring the revolution closer.

"Today the imperialist bourgeoisie militarises not only the adults, but also the youth. Tomorrow it may proceed to militarise the women. To this we must say: All the better! Go ahead faster! The faster it goes, the nearer shall we be to the armed uprising against capitalism." 20

Lenin then remembers a "certain bourgeois observer" of the Paris Commune who, writing to an English newspaper in May 1871, said: "If the French nation consisted entirely of women, what a terrible nation it would be." Lenin himself went on to observe:

"Women, and children of thirteen and upwards, fought in the Paris Commune side by side with the men. Nor can it be different in the forthcoming battles for the bourgeoisie. The proletarian women will not look on passively while the well-armed bourgeoisie shoot down the poorly armed or unarmed workers. They will take arms as they did in $1871 \ldots, 21$

This is the revolutionary fervour of which androgynous warriorhood is made. Leninist ideas are now slowly penetrating such countries as Mozambique, Guinea, Angola and Guinea-Bissau. A major sexual revolution in African conditions may be under way if such ideas do take root after a while.

And yet even in Lenin's own country true androgyny as a refutation of sexism is far from a reality as yet. Russia has discovered that the liberation of the proletariat is easier than the liberation of Russian women. And Mozambique and Angola may also discover that national emancipation is an easier target than equality between the sexes - least of all on the battlefield.

\section{Conclusion}

We have sought to demonstrate in this essay that three forms of resistance have been particularly important in Africa in the twentieth century. These are passive resistance, as championed by Mohandas Gandhi, primary resistance as manifested in the warrior tradition, and revolutionary resistance as embodied in the Marxist tradition.

Mahatma Gandhi's influence in Africa lasted mainly from the 1930's to the 1960 's. In the 1930's the Indian nationalist movement was already being followed with close interest in other parts of the British Empire. Politically conscious young Africans - especially in West Africa - were already drawing inspiration from the struggle in the Indian sub-continent.

By the 1940's the African struggle itself was gathering momentum. Kwame Nkrumah of the Gold Coast (later Ghana) was toying with Gandhi's ideas on

20 V. I. Lenin, "War Programme of Proletarian Revolution" (1916) Selected Works, Vol. I, (Moscow: Foreign Languages Publishing House, 1960), pp. 820-821).

21 Ibid. 
non-violent campaigns, and dreaming about translating them into what Nkrumah called "positive action" in his own fight against British rule. Nkrumah was aware that Gandhi had first used his technique in South Africa. What had not worked against white racism in South African might work against British colonialism elsewhere. Gandhian ideas thus helped to influence Nkrumah's approach to the struggle.

In 1958 - when Nkrumah hosted the all-Africa Peoples conference in the newly independent Ghana - neo-Gandhism was still relatively popular in much of Africa. The Algerian National Liberation Front - then engaged in an armed insurrection against the French - had a hard time persuading the Accra conference to give their armed struggle legitimacy and support.

In Southern Africa the most distinguished and most explicit disciple of Gandhi was Kenneth Kaunda of what was then Northern Rhodesia (now Zambia). Kaunda since then has become reconciled to violence under certain circumstances. Nevertheless, his flirtation with the idea of "détente" with white-dominated South Africa has probably been partly due to a residual neoGandhian faith that Kaunda has retained.

The late Albert Luthuli's belief in non-violent struggle against apartheid in South Africa was more a heritage of Christianity and the strategy of "turning the other cheek" than a product of conscious conversion to the ideas of Mahatma Gandhi. Yet who was to say where Christianity ended and Gandhism began in a politically conscious African in the second half of the twentieth century?

Since the 1960's Gandhism has drastically declined in prestige and importance in much of Africa. In Angola and Guinea-Bissau the anti-colonial struggle was gradually radicalised - and revolutionary resistance came into being. In Angola the triumph of MPLA (with Russian and Cuban support) also signified the victory of revolutionary forms of struggle. These radical forms of resistance have been substantially influenced by the Marxist tradition. It is true that Marx himself was more concerned with proletarian revolutions in industrialised countries. It was Lenin early in the twentieth century who came to address himself to the nature of imperialism. And it was Mao Tse-tung, Ché Guevara, Ho Chi Minh, Franz Fanon and Amilcar Cabral whl took the analysis further into the nature of struggling against imperialism.

All these philosopher-soldiers were influenced in varying degrees by Karl Marx and his ideas concerning class struggle and the necessity for revolution.

But affecting both passive and revolutionary resistance in Africa has been the resilience of primary resistance. We use the term here in the sense of struggle deeply imbued by aspects of indigenous military culture and African tradition generally. The colonial experience may have destroyed a large number of things in Africa, but many aspects of African culture have survived through it all. Colonialism was more successful in destroying organised African institutions than African values. It is true that the westernised Africans have, by definition, lost a substantial part of their culture. But these are only a small minority in their societies. Among the masses many traditional values and perspectives persist - including special definitions of such militarily relevant concepts as 
adulthood, fear, courage, discipline, honour, loyalty and enemy. When these norms are in a certain relationship with each other, and are sanctified by cultural ancestry and usage, they add up to at least part of the warrior tradition itself.

But combat and resistance reveal more than the attributes of the two sides in a fight. They tell us more than the nature of the fight itself. Combat and resistance reveal an additional piece of information seemingly unrelated to the fight - a piece of information which touches upon something as old as the origins of the human species. More important perhaps than the tension between the nationalist and the imperialist, between the socialist and the capitalist, is the relationship between men and women. How wars are fought is partly a lesson on how men and women relate to each other on issues of power.

It is because of that that the analysis in this essay has linked forms of resistance to forms of sexual arrangements and division of labour in society.

The warrior tradition in Africa - in spite of such exceptions as the Amazons of Dahomey - is a self-consciously masculine tradition, preserving warriorhood for relatively youthful males, and emphasising such hard virtues of manliness as valour and physical endurance. Primary resistance in this sense is therefore an undertaking overwhelmingly for men.

Passive resistance may be undertaken by either men or women but its values are culturally defined as feminine. They include the softer virtues of non-violence, love, and on accasion "turning the other cheek." Passive resistance is in part a politicisation of "sublimated maternalism."

Mohandas Gandhi had a "motherly" side to his personality, as we indicated. So perhaps does Kenneth Kaunda of Zambia.

It is with revolutionary resistance that androgyny as a refutation of sexist differentiation becomes at last a conscious aspiration. The term itself belongs more to women's liberation than to socialist thought, but the desire to liberate women was probably as strong in the philosophy of Marx and Engels as it is among radical feminists today.

"The ideal towards which I believe we should move is best described by the term "androgyny". This ancient Greek word-from andro (male) and gyn (female)-defines a condition under which the characteristics of the sexes, and the human impulses expressed by men and women, are not rigidly assigned. Androgyny seeks to liberate the individual from the confines of the appropriate." 22

Has female participation in the skills of violence been excessively regarded as "inappropriate"? Has the role of men in war been too "rigidly assigned"?

The militarisation of women in Southern Africa has at best only just started. The legacy of the Amazons of Dahomey will perhaps be radicalised in the southern parts in the continent in the years ahead. If the warrior tradition

22 Carolyn G. Heilburn, Toward a Recognition of Androgyny (New York: Harper and Row Publishers, 1974), p. x. Consult also Linda Jenness, (ed.), Feminism and Socialism (New York: Pathfinder Press, 1972) and Alfred G. Meyer, Marxism and the Women's Movement (Mimeo), Department of Political Science, The University of Michigan, Ann Arbor. 
in Southern Africa does get androgynised, a new dimension would be added to liberation itself. As colonies have got their independence, races their dignity and classes their rights, the women have so far been passively awaiting their turn. But now it is time for a change. In the words of a famous American musical "Annie, Get your Gun!" - for that is where power resides. ${ }^{23}$ Or so old Chairman Mao once told us.

23 In the musical "Annie, Get Your Gun" the woman could not be both a good shot and attractive to the man she loved. So she deliberately disguised her firing skills in order to win his love. In real life Annie should retain her fire power-if she wants liberation. 